以感り最シ羅大此叫费年一ル神

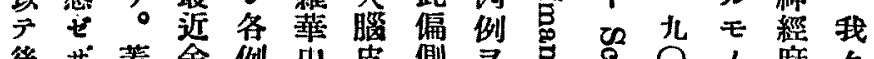

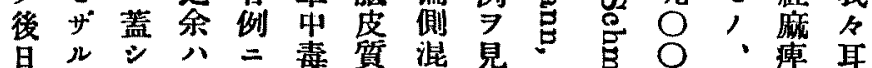

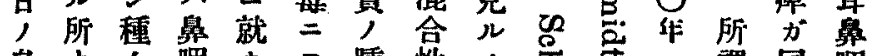

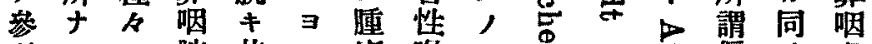

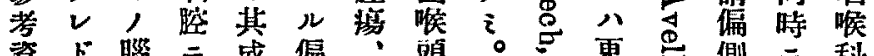

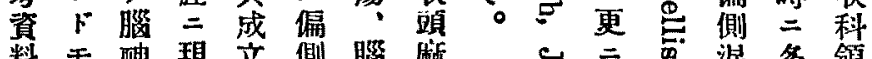

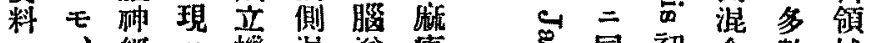
二、經八機混溘序憵同初合數域 供唯吕乞轉合血上要側

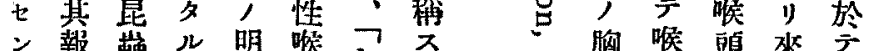

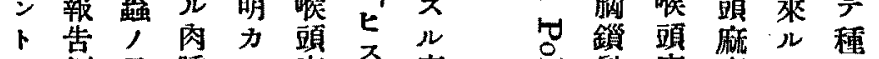

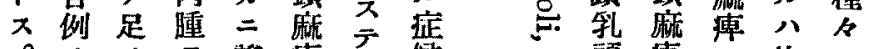

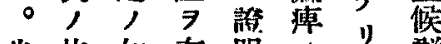
尚紫㠰有明, 群 種的 $ル 5$ 例等 成

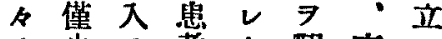
, 少入者夕䨳末 末

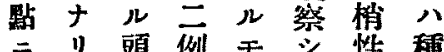

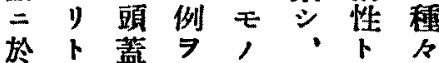

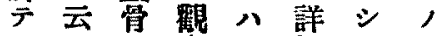
檢 7 㗨祭比細テ原 素以 蒌外斯'的儿頭考 $\not$ 二 其少檢蓋 不・肉經与索骨 三 充臨睡過ク, 底 分棼生所何果骨例 儿坷无謂 2 中扩全 八成儿偏モ桖: ハ 遗》時側推性亏 中

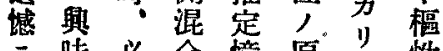
二味必合嬑原性 思樑然性测因兵卜 所經 繁噴 ナ過ノ魔儿テ董ハ

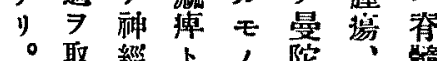

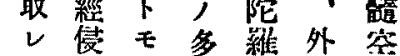

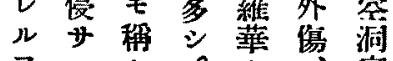

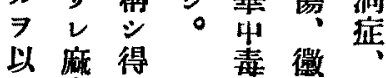

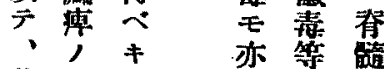

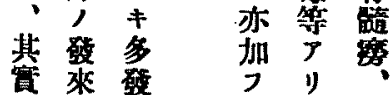

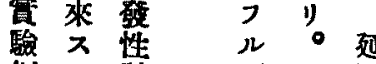
敒儿神可最赔 茹何程

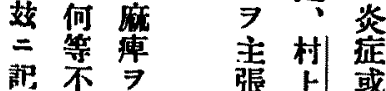

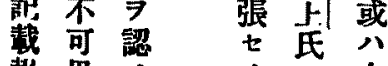

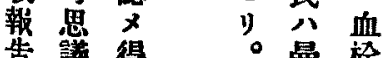

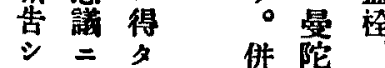

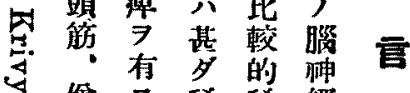
纽 諙 稀 稀

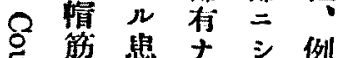
总后者出余 吸瘦 軟 經 特 它了疾二面 品儿蓋㭧同帅 發痻 す側經

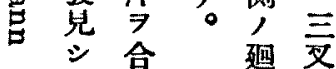

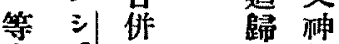
多繁等 人体來 報 氏 瘏 蹛 告 应 數 = 胂 候 例 加 り 群 $7>$ 等 ○藇 ル, 我程 國七ア 舌峐 $=$ ”。咽 個 於。“神公 テ 此 垂外 1 香章 垂永症 舌 氏紫候神爽 年群 䅬 最尽 近产副屋 代苞記 部 な 胃密籍

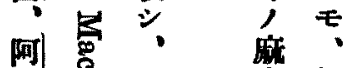

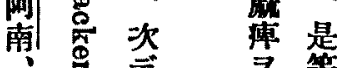

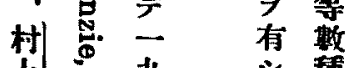

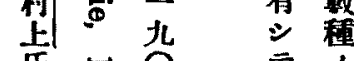
併陀、氐要

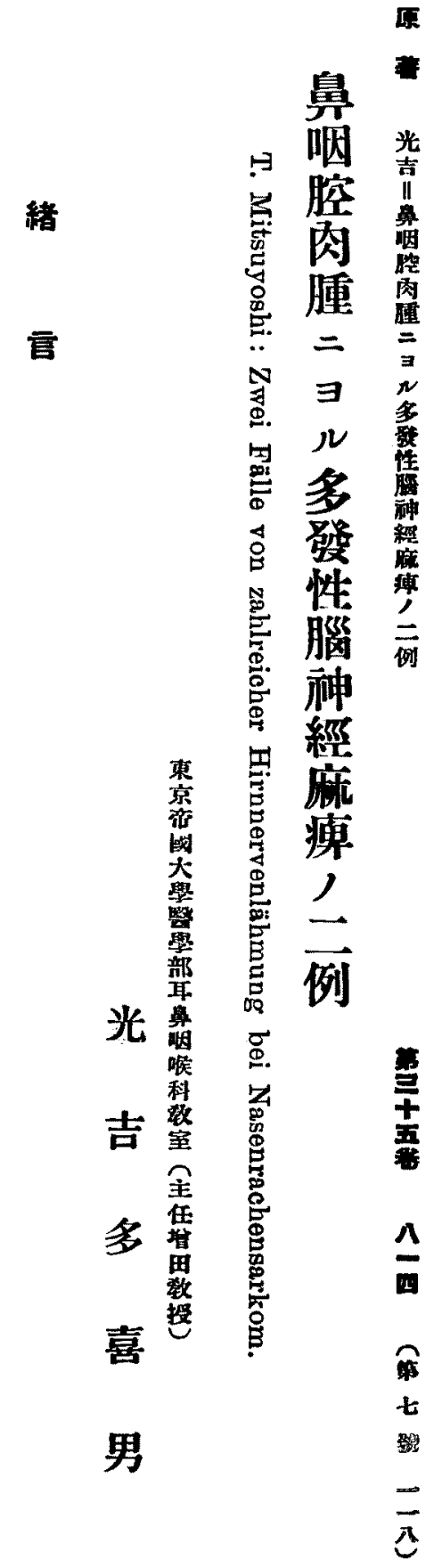




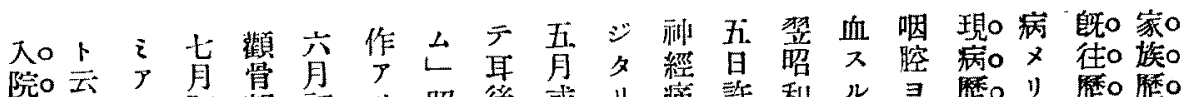

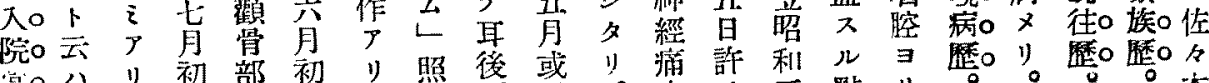

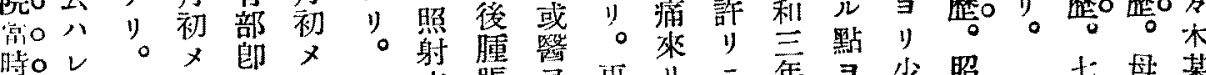

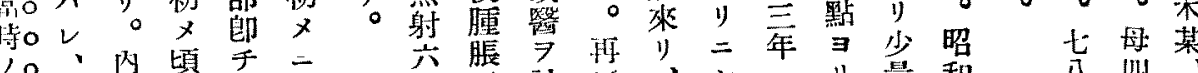

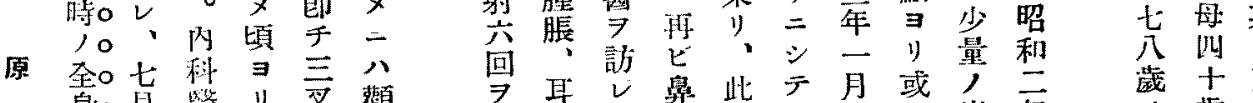

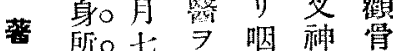
見。旦偝 頭 經

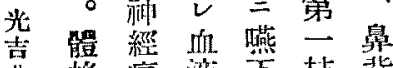
川格痛腹声枝背

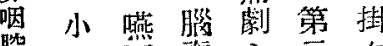

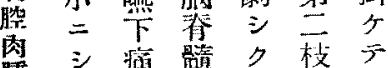
腫学留”强 $\exists$ 管複, 湤相斗

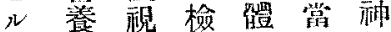
多公 箱稍主寻器儿痛 性了㴋受下部来 不占瓜年。

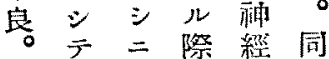
頻來何鼠痛月

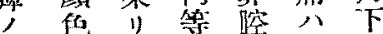
二讋直特三全旬 白二别逆品二 貧院所入笑耳 血七見ルシ 前 性 シ十栐、部 二厶力, 二 䇺 附 シ。劣古其 管 せ 二 儿桃皮嗔 右、院膚骨 眼六整知挂

\begin{tabular}{|c|c|c|c|}
\hline \multirow[t]{5}{*}{ 策 } & & & \\
\hline & I & $\stackrel{1111}{\exists}$ & \\
\hline & 陰 & リ & \\
\hline & 性 & 下 & \\
\hline & & 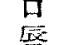 & \\
\hline
\end{tabular}

八存示监引

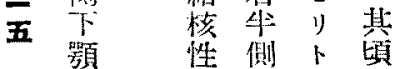

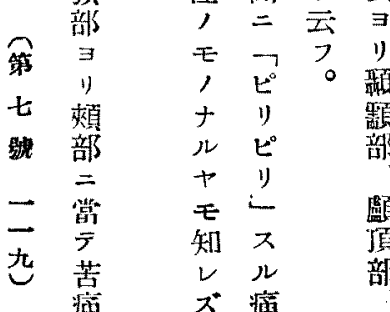

受菲

多等二腔忩邪肉血四

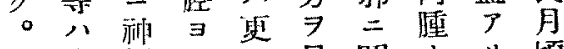

照全經り蓝見䍜ナル。貪

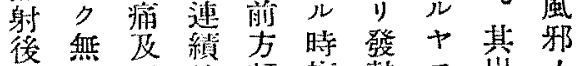

出力 $九$ 的額複熱モ出;

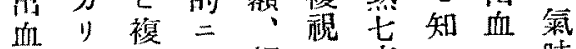

八中視血煩 $ア$ 鹿 $\nu$ 味

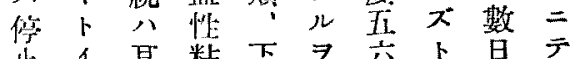

业 1 耳性液頙州分云間右 几。少, 部付分公結側 手手分二キ三 疼㼻, 泌技眼一夕此, 痛後ナ学散求日り血難

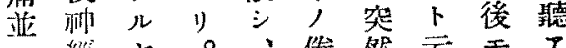
$=$ 經 + 䙡 痛 预? 知 依襩 然尖卜 何, 等 疑 テ 輻 二 存減 宁 シ た 右 特资 二故 蝔 $\neg$ 二绳 今或 起 ヂハ, ウ肉開 亡 腫 警 $\Rightarrow$ 夕 7

紧丈商

七

\section{ル 2}

夜

八, 力

虽 事

劇 $\overline{\bar{\sigma}}$ 際

烈舆 蜼

$t$ 咽 褔

ル貯

訮 $=y$

紃 ᄀ

痛

臂方
其意然云忘吉り

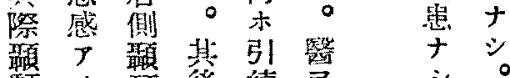

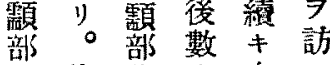
、䙉附方血レ 頙祲近月性 シ 頂八三間粘二 部夫劇少液 歌 人烈量, 氐 崕來儿り泌狹

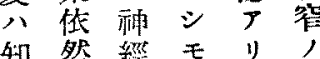
然然桱 モ ”。

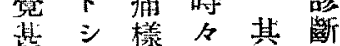
ダ テ 疼出時, 痳 過䄷痛血鼠下虫造

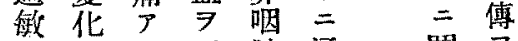
卜七り反貯通躍 7

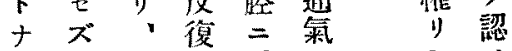
リ $⺊$ 疼 $七$ 睡 $\exists$

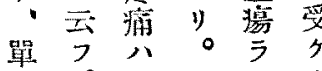
$=0 \%$ 帛 手三百手 指月鉒云云

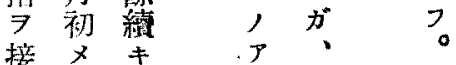

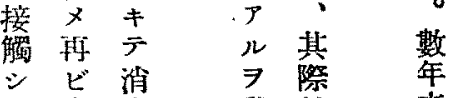
右先 モ 側 七 疼 頙 ”。 痛顬 感 $=$ 後

燈粘腽 \# 、稘 出鼻
血

$=$ t 峲 歲 、肺 核男 驗 第 例 


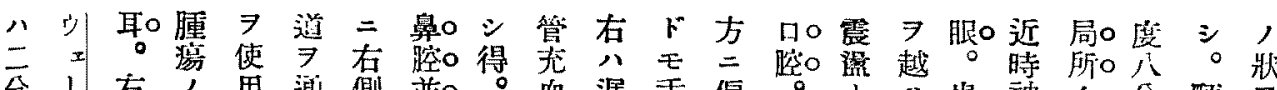

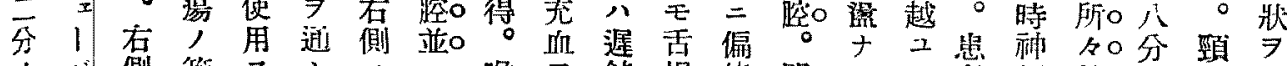

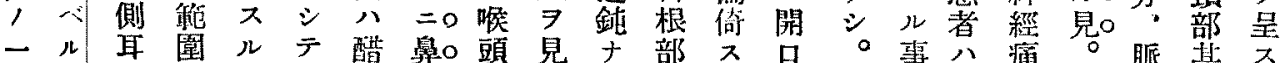

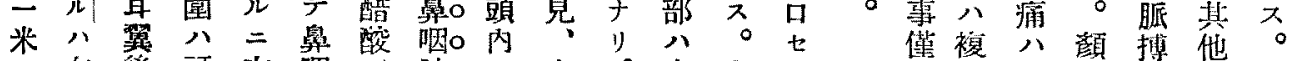
二右後可左咽子腔。二右。右右三吕視此面七, 瞳

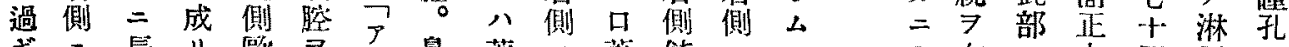

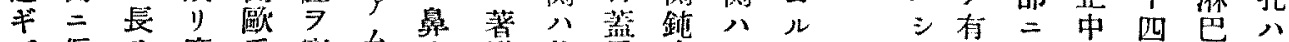

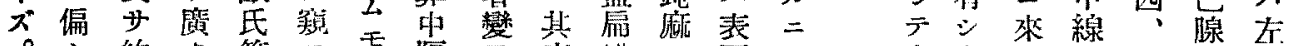

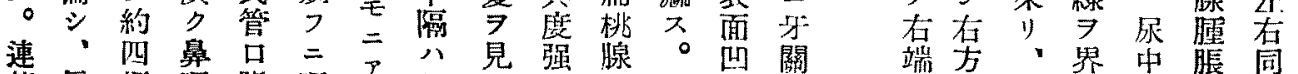

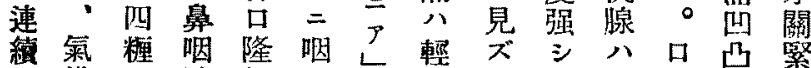

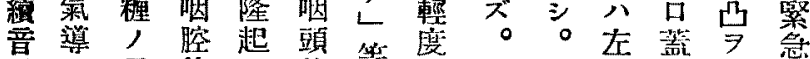

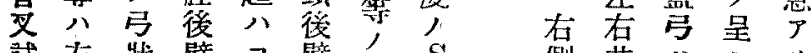

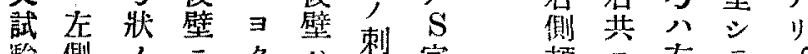

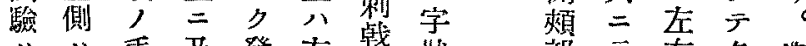
八刀手及發在战狀部示右多潮 七略術ビ蓬側性彎 指不少另

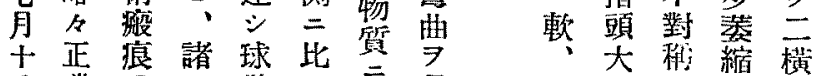

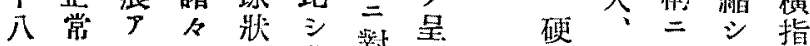

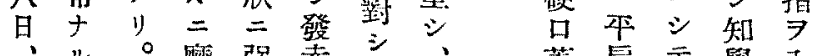

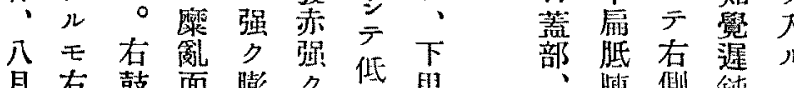

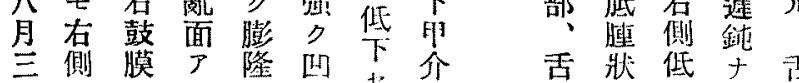

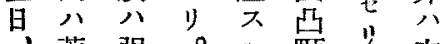

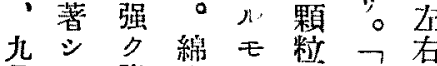
月ク陷卷、茯 共 十短没三右, 1 =

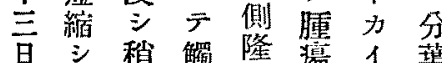

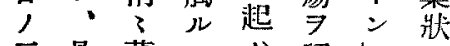
三骨萎、公認レニ

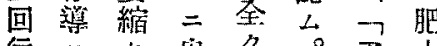

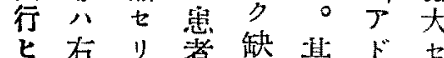
多后り側者缺其ド巷 少延通右シ、流

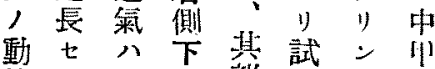

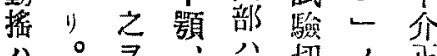

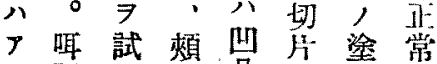

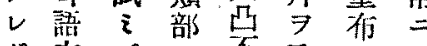
左 $ス ゙=$ 不取 三

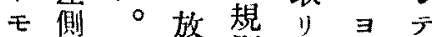

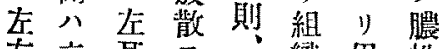

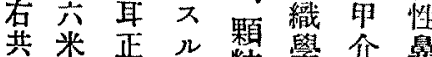
共米正品粒學芥鼻

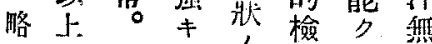

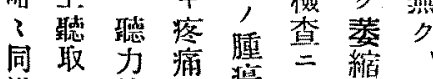

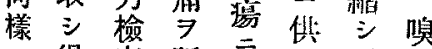
シ得查訴彎 ス。右 テ 示行。华後后 7 下右 根二下 ”。 後

咽 數 䉳、 頭 個 $x$ 酸 三

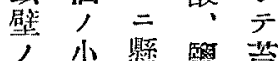

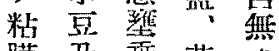
膜而丟笑 至 知 大端 味 挻 覺 豆 $八$ 覺 鈍大望 $\Rightarrow$ 七 磨、方 檢 砦二 入ム 白候儿ル

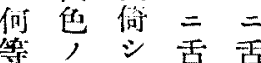
䟽腺、前尖 璃窝被部著 7 䚈 施腫際交方 ザ胃祭右否 シ罗左常 テ。侧 二偏

口後口三偷

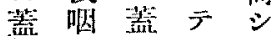
屺頍弓大引 高壁八蕉艾 舉 八高 $\Rightarrow$ L 器 少奭 認 ル $\Rightarrow$ 数 入 $x$ 際 使甪血モぜ主 二 7 下児 $+大$ 份見㖘立白至 禾際唇宁右糖腹テ 色八右側陰部圓 公特坐要性, 形 結二側攴。諸 膜其八神 自度特經 几增過第 。拂 敏 眼入枝 科ルり文 䂑 7 ト ビ 洤云第 尩フ。フ店

宁眼 检球支 ス 7 毁 儿有領 右 = 側固定

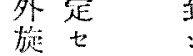
利 シ う 繁台整 培時云

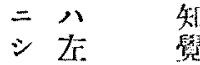
テ 側 服分釛 底其 麻 二極 八位 異 $\Rightarrow$ 管取第 見卡积 ズモ采音 卜、知馠聞

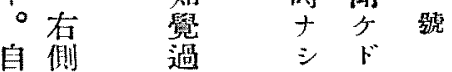
自侧過 發 敏 性 正 眼 中 球綠

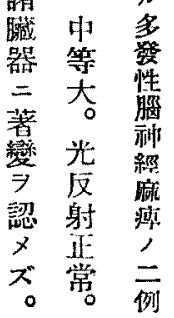

肯哀 下 界 , 证 腱常 射 右 正 湖 常 尖 喕

面於 以打 部咅 二 知 知 覺策 㳳 枝

政音 解

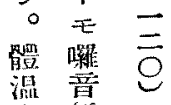




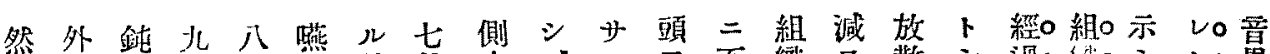
科麻月月尔神月方:三至織

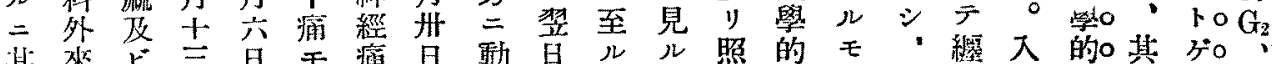
其來

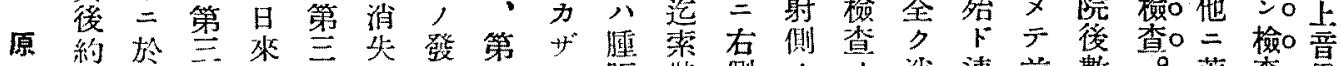

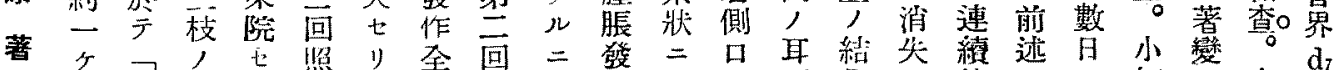

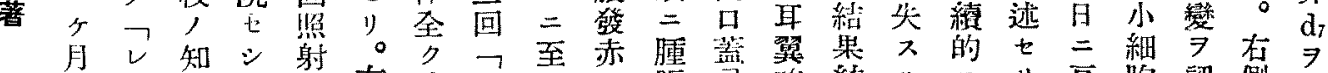

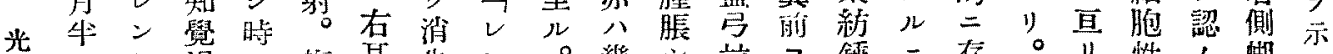

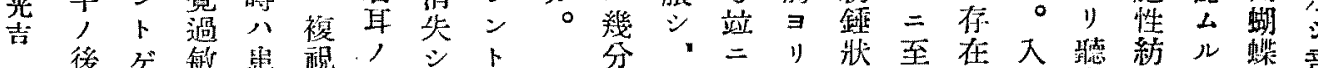

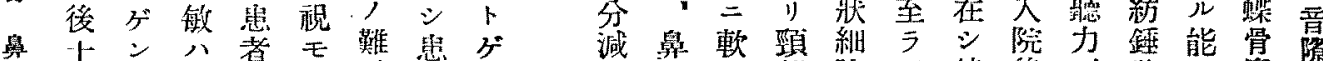

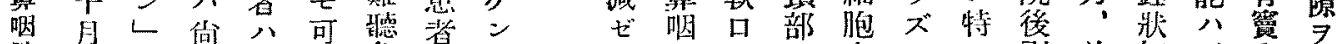
腔兰照木谌成念甚

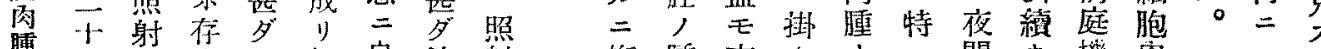

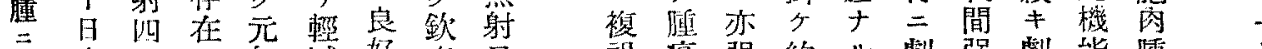

$\exists$ 來回音氣隇好薏

$\sim$ 院 $\Rightarrow 、 卜 シ 130$

多七受時

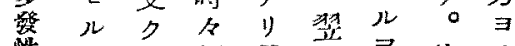

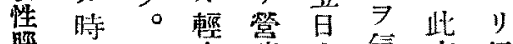

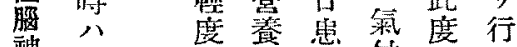

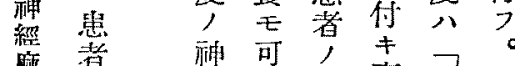

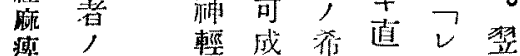

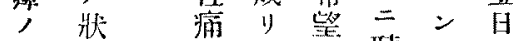

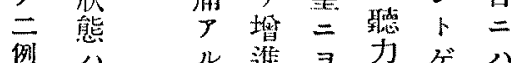

前匹進寻掏

回激少一查亡 章

r烈。先 7 照融

全 $ナ$ 襩济ナ射經

少視退七二第

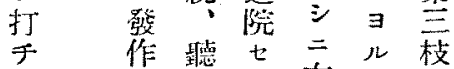

變八力シ 右反,

1) 全八 $x$ 側 憵 知

- 多胳 時 八炎覺

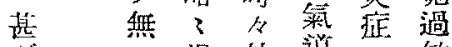

多 沙退咅 分敏

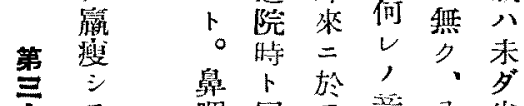

要

呕同灾章公向

苦腫三祭稍白存

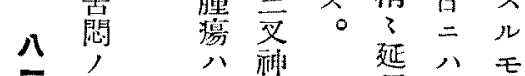

七狀荅經長發

視演强約儿劇强劇能霾

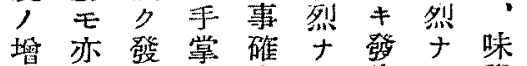

惡浮亦大等儿作儿覺

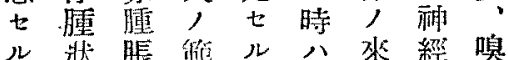

$=\stackrel{シ}{=}$ 園 $=-7$ 痛覺

莱腫、湤 $コ$ パ 7 检

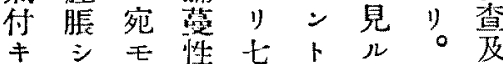

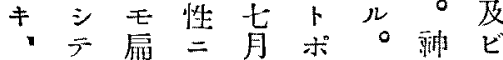

檢其桃發せン其經組

乙袁腺赤七乚都痛織

儿面社䐟日, 度八標

二㦄圍脹朝注

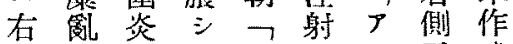

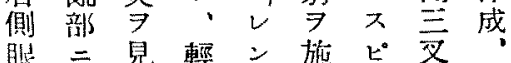

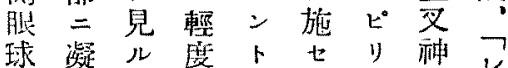

分血が息がリン經さ

右㘿如厤之一七第上

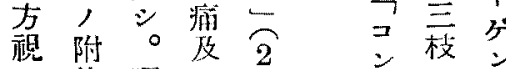

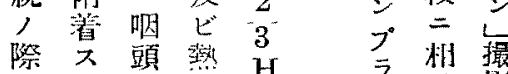

皆儿後感 $\mathrm{H}$ ，當影

シ $\exists$ 壁学 $\mathrm{E}$ 九祭

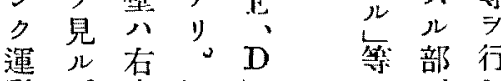

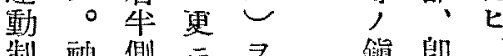

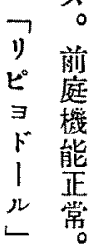

絈

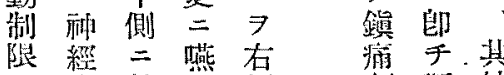

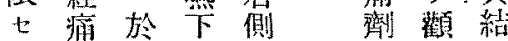

亏分唒頸 $\Rightarrow$ 骨果

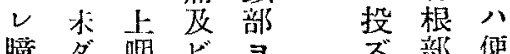

泉, 新今

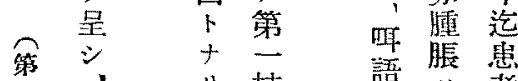

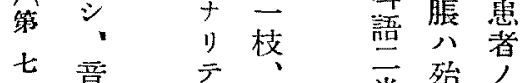

㩆㢣萎第米佲最

孔多膑㔨 j

八少 $\exists$ 盟

正存"困射

中在會蜼

儿主

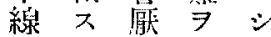

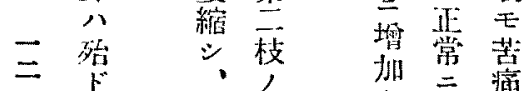

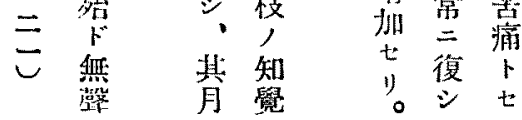

$\exists ル$ 僌 挀二

り七骨人、

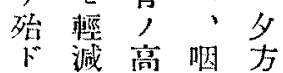

二秒䫅文

$\zeta$ 部、院

$\stackrel{c . c}{\Rightarrow}$

注

太

$\bar{\tau}$

前

後

右

,

向

寫

辈

七

シ

$=$

的

悬

正

䌡一下 時

痛顎

輕

正

陰 


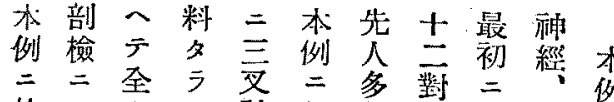
於寻名神於数鼠舌八

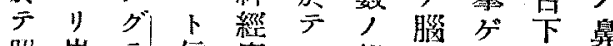

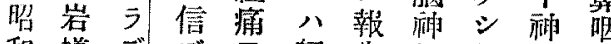

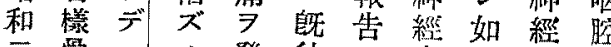

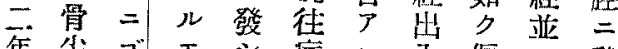

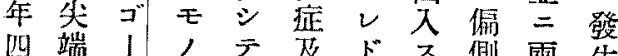
月ヨ症ナ來芒モ側雨生 病少候”其本頭合迎ル

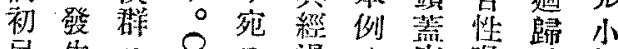
已生三尺期, 過, 底喉敊細 鼻儿致

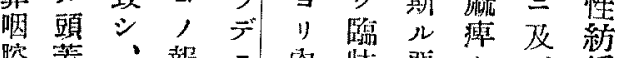

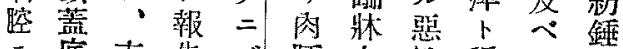

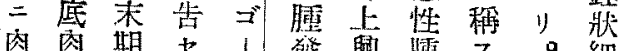

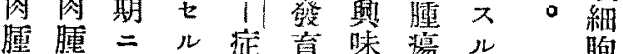

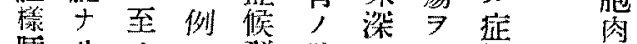

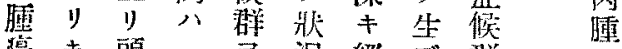

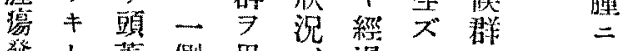

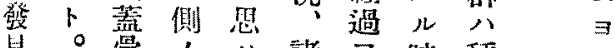
兄。骨了八諸 $尹$ 時種光

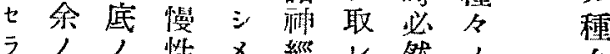
う例殆性 、經儿然, 原,

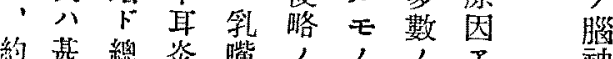

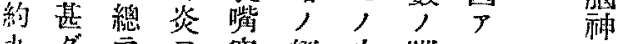

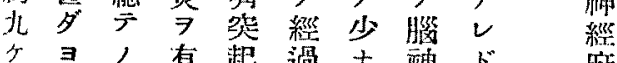

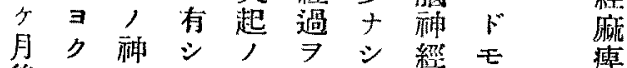

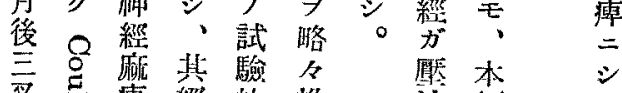

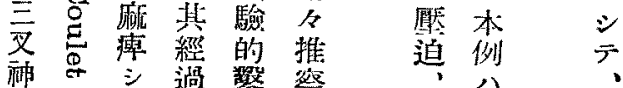

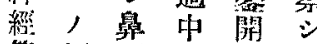
第 例 咽 同 $\Rightarrow$ 得

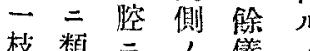
, 似硬外篦 融七固旋方与 經り 痛

ビ 腫 脚 $x$

外瘍壆名其

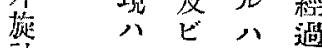

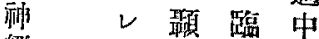

經 夕顧棼 外

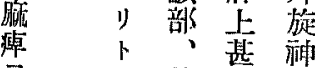

$\Rightarrow$ 云 後 多 䊷

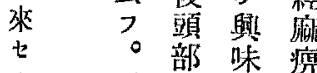

ル 而, 䑙, 桨

八 $\quad$ 冷

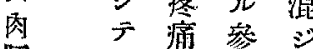

死 7 考同
浸阔喠侵

$= \pm \quad \forall$

$\exists \quad \exists \quad$ ᄂ

隚米名

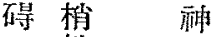

$\Rightarrow$ 性緭

准

蝻 側

明皆亥

+ 可 矿

リ方經

斯 ザ 外

ル ル 旋

症モ神

(例) 縚

$=$
就 $シ$

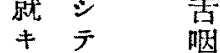

其其樣 位硬シ 常。然生, 歸索泡取轉知, 。, 桑態

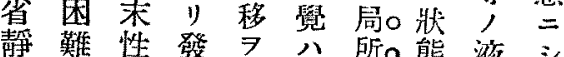

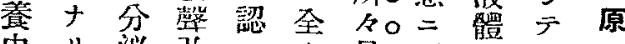
中り泌改台》男。至 7 頻

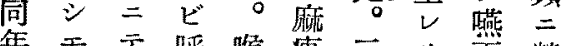

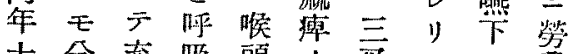
十分売吸頭, 齐卜不泪

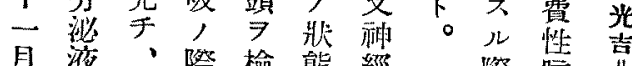

第十液!際檢熊經 際喛川

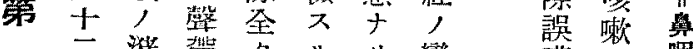

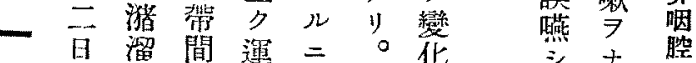

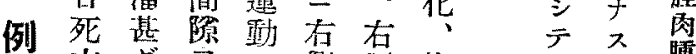
考七 按り

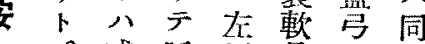

或㭔㑡骨八榜 八叫整 八固 其卜带少定存

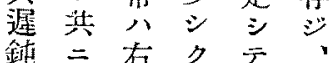

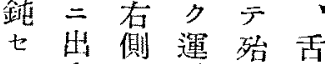
ル入二醉 二 不 比斬 挺 非。方 ザ知裙モ ズ七 其 レ

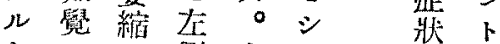
$ヤ 八 ッ$ 侧有山只 ７右テ报側ル 次 思側幅 裂 胸二第し

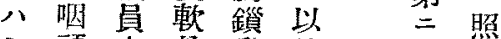
シ頭小骨乳前 增 射 厶後卜 $卜$ 頭 $\exists$ 惡 $\Rightarrow$ 壁子多解り 妾受

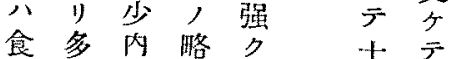
道少後方右明 入岛古中方, 舍 口緩三央三初虽 部七喠 三鼬皇帚 迄儿位觔修何り

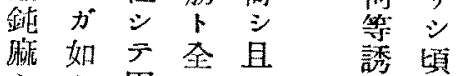
* $\%$ 固名寻

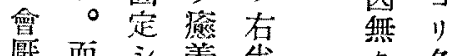

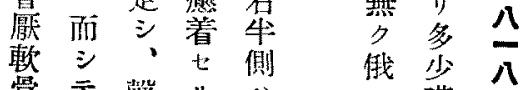

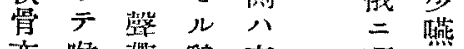
亦呢滞鷂表 嗄

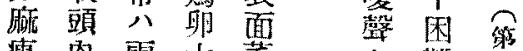
瘵丽网大萎谁的

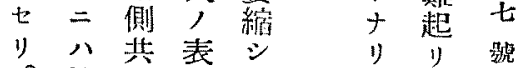
。粘 二面方 喉液牛叮听

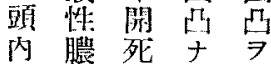
八计體 ル 呈 


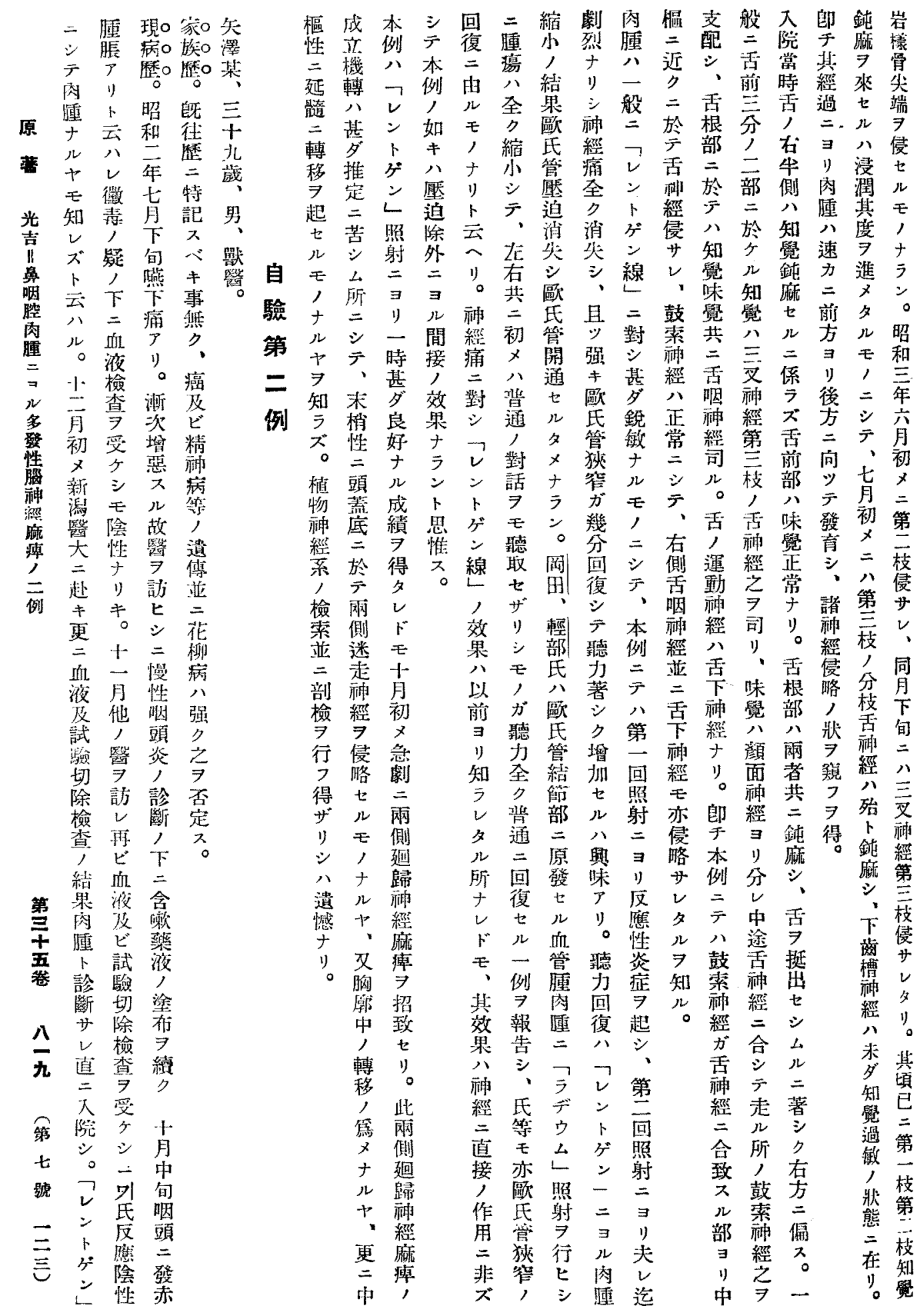




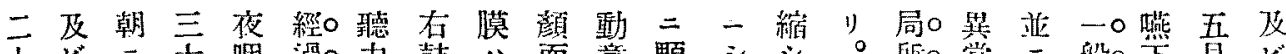

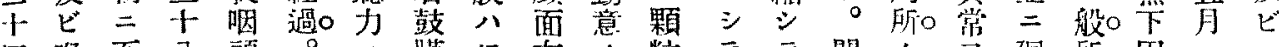

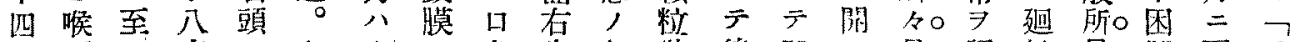

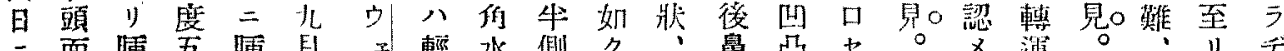

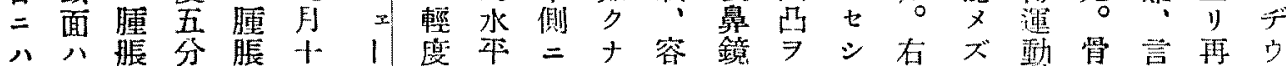

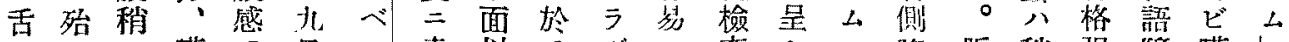

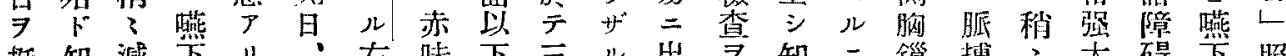
挺知減下り, 右味下三儿出

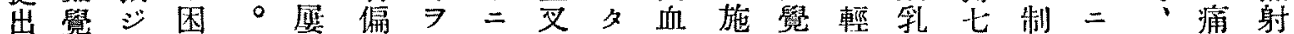

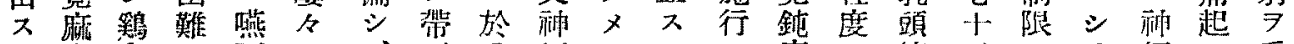

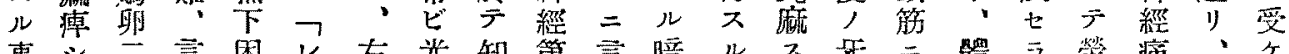

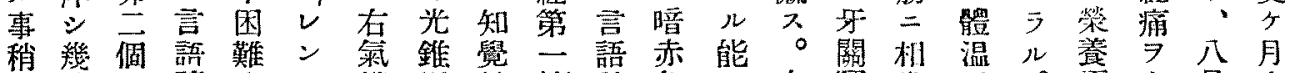

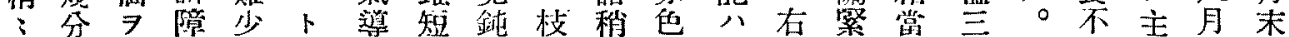

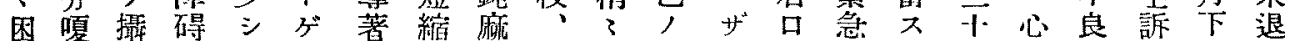

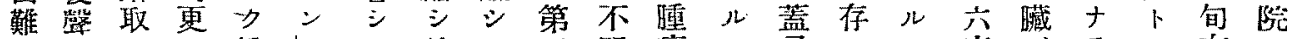
$=卜 シ$ 增

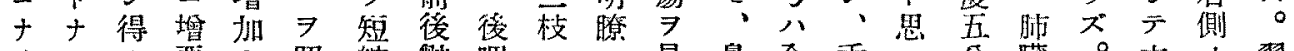

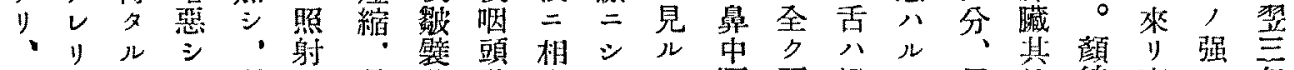

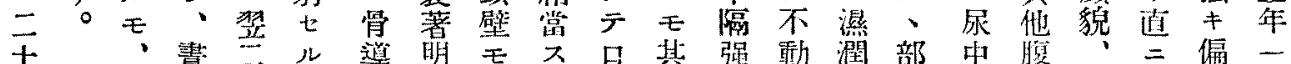

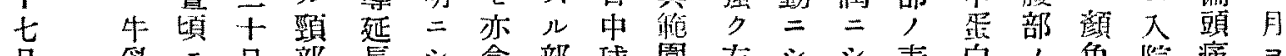
旦 孚三旦部長

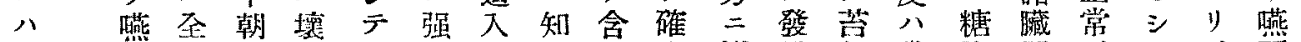
全等

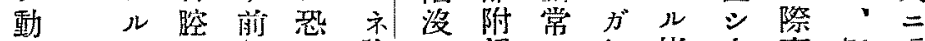

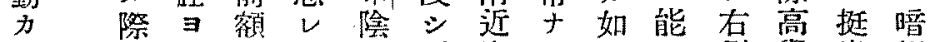

ス 氣 リ: ア 性近迄儿シ八側擧出褐

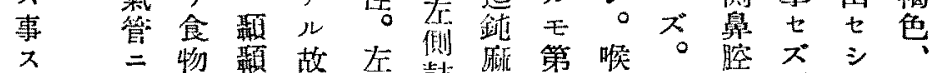

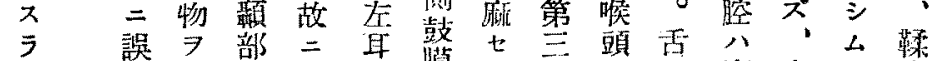

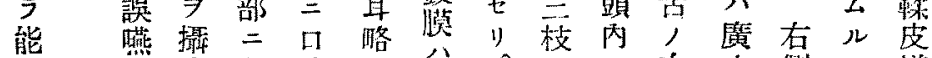

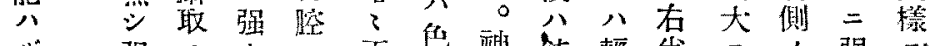

ザ 强入キ正急神鉬輕牛二, 强二

ル キ

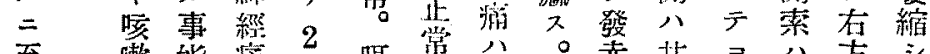

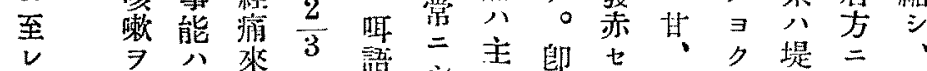

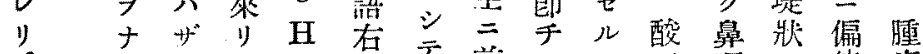

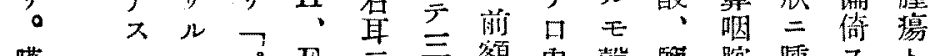

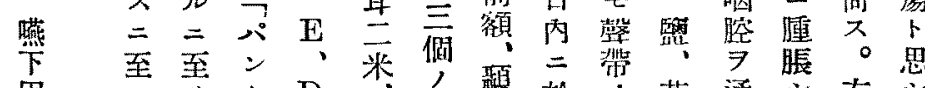

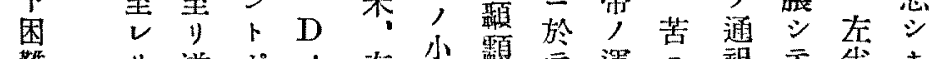

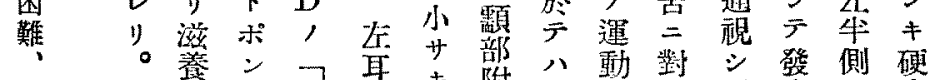

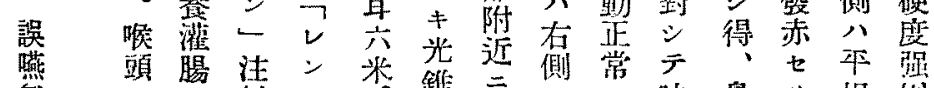

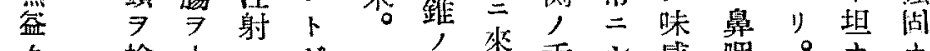

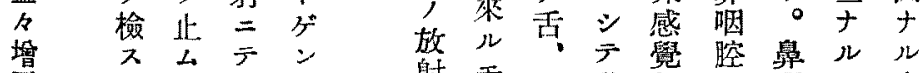

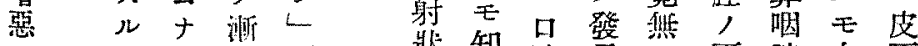

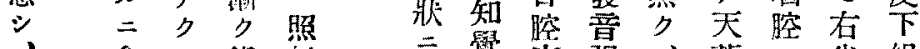

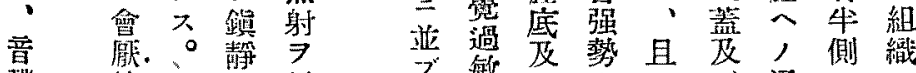

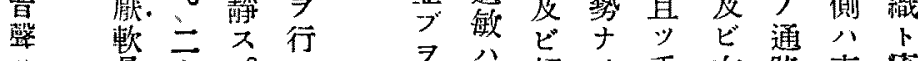

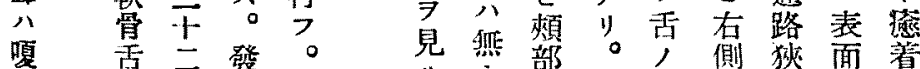

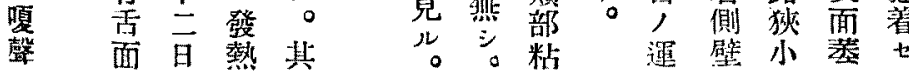

著斯碍 


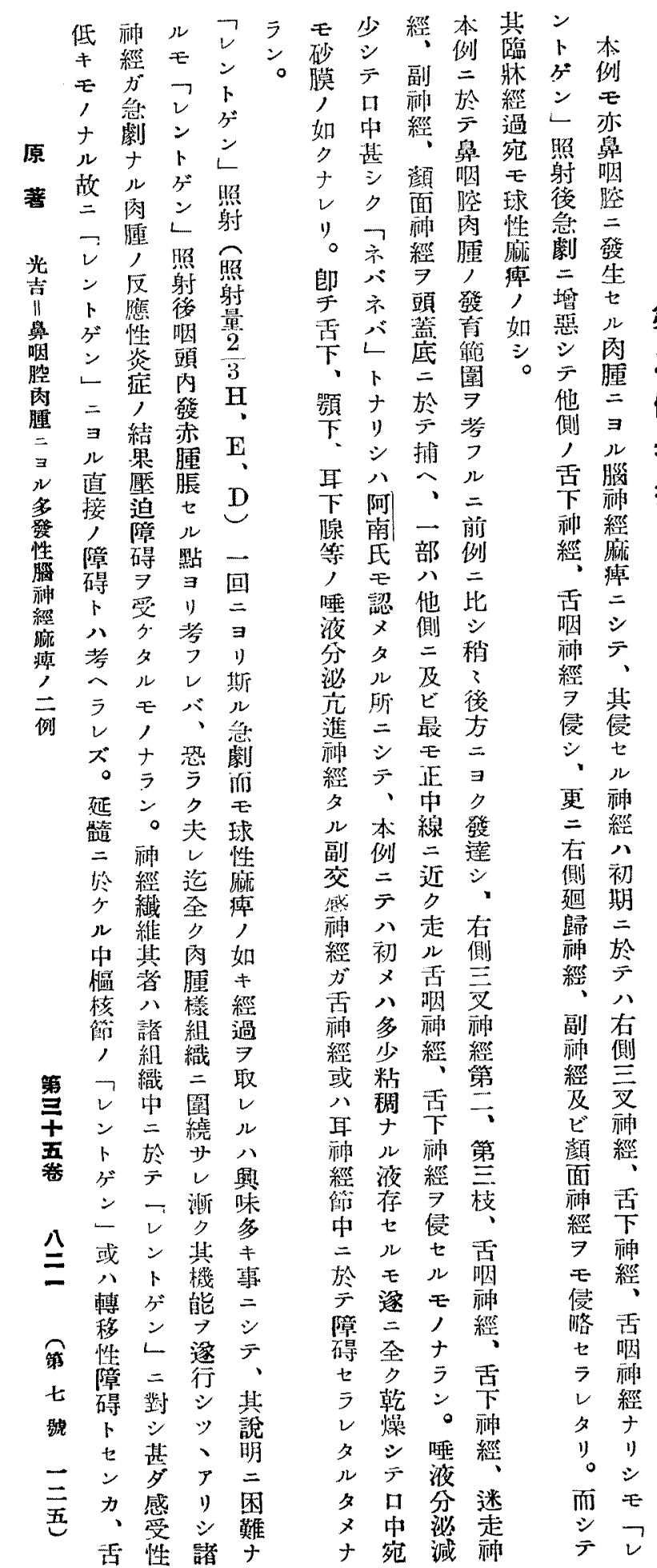

都賞二殘ズ。面用渴二 合瘦干存。神シ動 シ 三シ九，ス右綴テ障テ ヨテ云儿侧, 喉碍且 y一、上不頭八\%

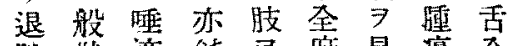
院狀液鈍 7 嫲罢瘍全

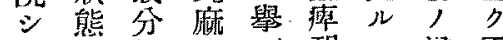
歸日泌シ少現二浸不 省々强、ルハ、潤動 靜二ク只二し左,

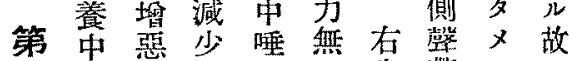
二十シ $シ$ 液 $\neq$ 牛帶二= 例 1 全

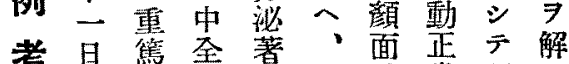
死卜名者右筋常運 按亡ナ乾》側肉ナ動几 七レ蜗隇局㢩几袖能 り。”シ, 少留緩圭經八 脈点テ稍テ側磨。 細 $\Rightarrow$ 量下 $>$ 帶二頭 小被, 垂 又八 $、$ 檢 、ル粘七刀牛ル查

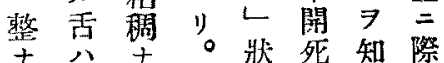
ル 公 ル 㱜 ル 网 緊漛六握り二且舌 張苔公力、固产 弱, 公鬼定何口 少生年共眼シ、等 百夕强呈其布ゼ

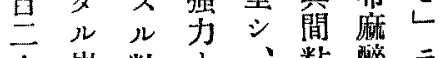
平岩粘ナ、粘醉二 餘石液り鼻棝 $尹$ 包

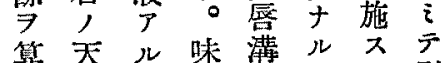
旦, 礐消粘事引 、 $=$ i 檢先液無 品

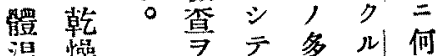

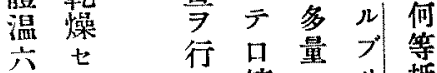
度山笛 代古二马附之抗 二如析着 降 七大秋八 ”院部口見會 。後, 唇ル罪 7 艒 一 $\Rightarrow$ 。整 得 者 小尖更骨

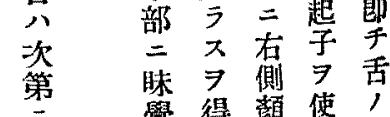



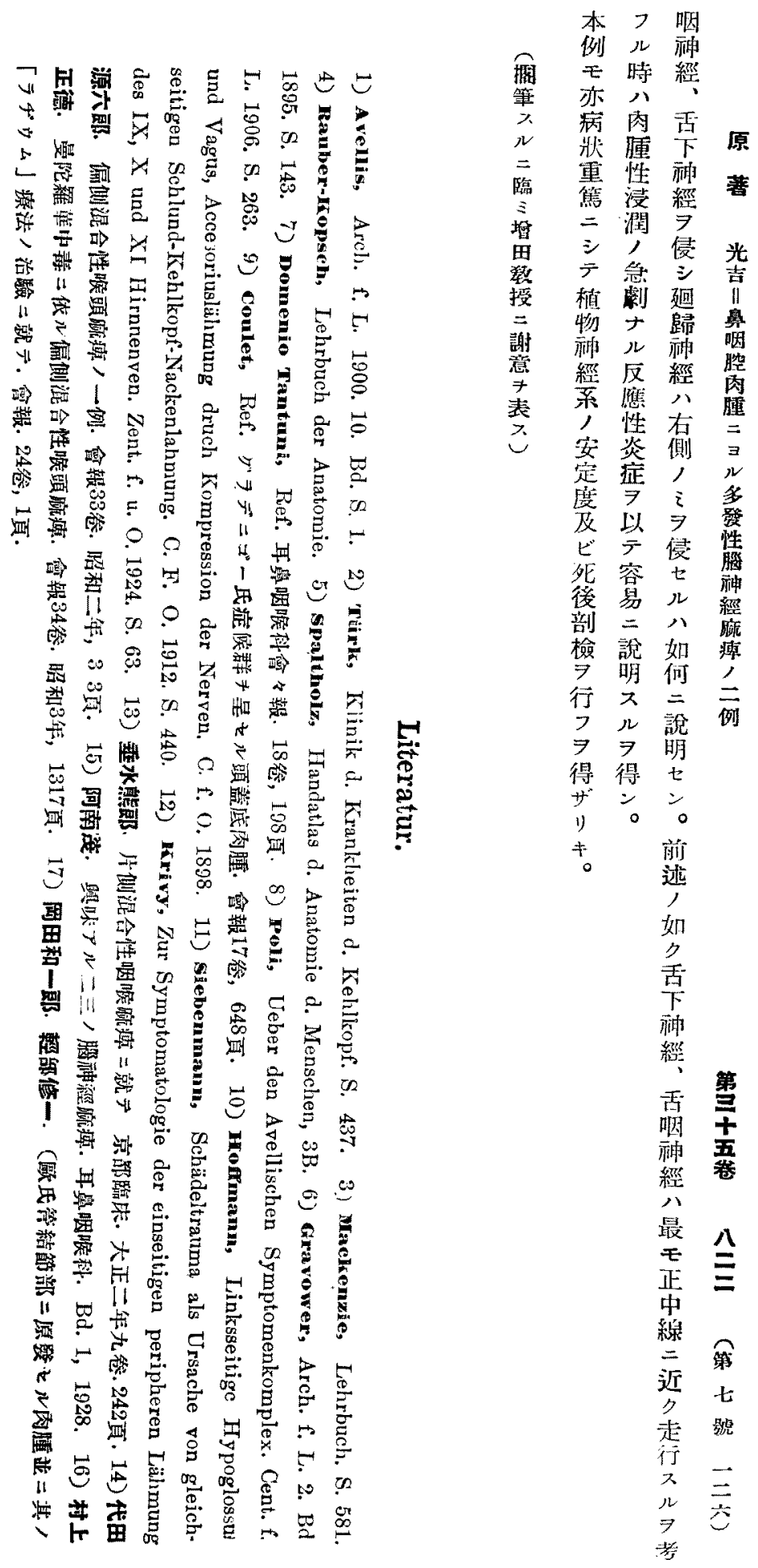